\title{
Faktor-Faktor yang Mempengaruhi Tingkat Kecemasan Perawat Covid-19 Selama Pandemi di Indonesia
}

\author{
Factors Affecting the Anxiety Levels of Covid-19 Nurses During the Pandemic in \\ Indonesia
}

Rudi Haryanto*, Zahrah Maulidia Septimar

Program Studi Sarjana Keperawatan, STIKes Yatsi Tangerang

\author{
*Korespondensi Penulis : \\ Rudi Haryanto, \\ Email : rudi18haryanto@gmail.com
}

\begin{abstract}
Abstrak
Latar Belakang: Perawat yang terlibat langsung dalam penanganan dan perawatan pasien COVID-19 beresiko mengalami gangguan psikologis. Tujuan dari penelitian ini adalah untuk mengetahui faktor-faktor yang mempengaruhi tingkat kecemasan pada perawat yang merawat pasien COVID-19 selama pandemi di Indonesia. Metode: Penelitian ini merupakan penelitian cross-sectional pada 336 perawat yang merawat pasien COVID-19 di rumah sakit di berbagai wilayah di Indonesia. Pengambilan data penelitian ini menggunakan kuesioner Hospital Anxiety and Depression Scale (HADS) versi Indonesia, kuesioner data demografi dan kuesioner dukungan rumah sakit yang disebar secara daring melalui google form. Hasil: Hasil analisis dari 336 orang perawat COVID-19 terdapat 27\% yang mengalami cemas ringan, $20,8 \%$ cemas sedang, dan 2,7\% cemas berat, serta 48,8\% tidak mengalami kecemasan. Tingkat depresi mempengaruhi tingkat kecemasan $(\mathrm{p}<.000, r=0.451)$. Dukungan rumah sakit yang baik menurunkan tingkat kecemasan $(p<.000, r=-0.278)$. Perawat COVID-19 yang telah menikah/ berkeluarga cenderung memiliki tingkat kecemasan yang lebih tinggi dibandingkan dengan yang masih sendiri. Kesimpulan: Status pernikahan, dukungan rumah sakit dan tingkat depresi merupakan faktor-faktor yang mempengaruhi tingkat kecemasan pada perawat COVID-19 di rumah sakit. Dukungan rumah sakit merupakan faktor yang signifikan mempengaruhi tingkat kecemasan.
\end{abstract}

Kata kunci: perawat, Covid-19, tingkat kecemasan, dukungan rumah sakit.

\begin{abstract}
Background: Nurses who are directly involved in handling and treating COVID-19 patients are at risk of experiencing psychological issues. The study aims to determine the factors that affect the level of anxiety among nurses who treat COVID-19 patients during the pandemic in Indonesia. Method: This research is a cross-sectional research on 336 nurses who treat COVID-19 patients in hospitals in various regions in Indonesia. The research data was collected using the Hospital Anxiety and Depression Scale (HADS) questionnaire in the Indonesian language, a demographic data questionnaire and a hospital support questionnaire distributed online via Google Form. Results: The results of the analysis of the data collected from the 336 COVID-19 nurses revealed that $27 \%$ of the respondents experienced mild anxiety; $20.8 \%$ had moderate anxiety; $2.7 \%$ had severe anxiety; while $48.8 \%$ did not experience any anxiety. It was also found that depression levels affected anxiety levels $(p<.000, r=0.451)$. Good hospital support decreases anxiety levels $(p<.000, r=-0.278)$. Covid-19 nurses who are married/have a family tend to have higher levels of anxiety than those who are single. Conclusion: Marital status, hospital support and depression levels are the factors that affect the level of anxiety among COVID-19 nurses in hospitals. Hospital support is a significant factor affecting anxiety levels.
\end{abstract}

Keywords: nurses, Covid-19, anxiety levels, hospital support. 


\section{Pendahuluan}

Sejak Desember 2019, virus corona jenis baru yang disebut novel coronavirus (2019-nCoV, atau COVID19) telah diidentifikasi di Wuhan, China. COVID-19 kemudian berkembang pesat dan menyebar ke seluruh China dan dunia. Penyakit ini dapat menyebabkan gejala termasuk demam, kesulitan bernafas, batuk, dan lesi invasif pada kedua paru-paru. ${ }^{(1)}$

Menghadapi situasi krisis seperti ini, perawat sebagai tenaga kesehatan garis depan yang terlibat langsung dalam penanganan dan perawatan pasien COVID-19 beresiko mengalami stress psikologis dan gangguan psikologis lainnya. Hal ini ditambah dengan beban kerja yang semakin meningkat, belum tersedianya obat yang spesifik untuk penyakit ini, semakin meningkatnya jumlah pasien, kurangnya alat pelindung diri, kurangnya dukungan dari pihak-pihak terkait, serta adanya stigma yang muncul di lingkungan tempat tinggalnya. ${ }^{(2)}$

Beberapa studi sebelumnya telah melaporkan adanya hubungan antara wabah baru di suatu wilayah dengan peningkatan masalah psikologis pada tenaga kesehatan di wilayah tersebut. Studi terkait dengan adanya stress/ trauma psikologis pada para dokter dan perawat selama menangani wabah
Avian Influensa tipe baru (H7N9) telah melaporkan adanya tingkat posttraumatic stress disorder (PTSD) yang tinggi. Faktor resiko yang diidentifikasi antara lain profesi perawat, wanita, usia 20-30 tahun, pengalaman kerja kurang dari 5 tahun, belum pernah mendapat pelatihan khusus yang terkait, serta belum memiliki pengalaman dalam merawat pasien yang sama. ${ }^{(3)}$ Studi lainnya di China membuktikan adanya peningkatan masalah kesehatan mental pada tenaga kesehatan yang bekerja langsung pada area yang terpapar wabah COVID-19 di Wuhan dibandingkan dengan tenaga kesehatan yang bekerja di wilayah lainnya di luar Wuhan. ${ }^{(2)}$

\section{Metode}

Penelitian ini bertujuan mengidentifikasi faktor-faktor yang mempengaruhi tingkat kecemasan pada perawat COVID-19 yang meliputi karakteritik, dukungan RS dan depresi. Subyek dari penelitian ini adalah perawat yang bekerja di rumah sakit yang berada di area yang telah ditetapkan menjadi wilayah tanggap darurat COVID-19 di Indonesia. Penelitian ini merupakan studi crosssectional. Teknik pengambilan sampel pada penelitian ini adalah teknik nonprobability sampling dengan metode convenience sampling. Kriteria 
inklusi dari penelitian ini adalah bekerja di rumah sakit, berusia 18-65 tahun, dan pernah merawat pasien COVID-19, dan menyelesaikan survey yang telah diberikan. Sedangkan kriteria ekslusi dari peneltian ini adalah perawat yang belum pernah merawat pasien COVID19.

Pengambilan data penelitian ini menggunakan kuesioner yang sudah baku yaitu Hospital Anxiety and Depression Scale (HADS) versi Indonesia, kuesioner data demografi dan kuesioner dukungan rumah sakit yang disebar secara daring melalui google form. Kuesioner HADS versi Indonesia di adaptasi dari Rudy (2015) yang telah dilakukan uji validitas dan uji reliabilitas sebelumnya dengan hasil yang baik. ${ }^{(4)}$ Sementara kuesioner dukungan rumah sakit terdiri dari item persepsi perawat terhadap dukungan manajemen Rumah Sakit, ada/tidaknya pelatihan khusus terkait COVID-19, ketersedian panduan/ Standar Prosedur Operasional (SPO), ketersediaan Alat pelindung Diri (APD), dan ketersedian ruang isolasi sesuai standar.

Responden yang diperoleh selama proses penyebaran kuesioner secara daring selama batas waktu 30 hari sejak tanggal 15 Mei 2020 hingga 13 Juni 2020 adalah sebanyak 370 orang.
Namun demikian, setelah dilakukan penyesuaian dengan kriteria inklusi dan ekslusi diperoleh jumlah responden sebanyak 336 orang (34 responden diekslusikan).

Analisa yang dilakukan adalah univariat dan bivariat. Perbandingan antara dua kelompok dilakukan menggunakan Mann Whitney $U$ test dan perbandingan antara beberapa kelompok dilakukan menggunakan Kruskal Wallis test. Korelasi antara masing-masing variabel dengan tingkat kecemasan dilakukan menggunakan Spearman Rho correlation.

\section{Hasil}

Dari 336 responden mayoritas adalah wanita $(71,4 \%)$, berusia $31-60$ tahun $(59,8 \%)$, telah menikah $(70,5 \%)$, masa kerja 5-15 tahun (54,8\%), telah lebih dari 10 kali kontak dengan pasien COVID-19 (62,8\%), bekerja di ruang isolasi selama pandemi (27,7\%), bekerja di ruang rawat biasa sebelum pandemi (35,7\%), tinggal di rumah milik pribadi $(46,1 \%)$, dan tinggal bersama suami/istri/anaknya 51,8\%) (tabel1). 
Tabel 1.Karakteristik Responden $(n=336)$

\begin{tabular}{|c|c|c|}
\hline Variabel & $\mathbf{n}$ & $(\%)$ \\
\hline \multicolumn{3}{|l|}{ Umur } \\
\hline - 20-30 Tahun & 135 & 40.2 \\
\hline - 31-60 Tahun & 201 & 59,8 \\
\hline \multicolumn{3}{|l|}{ Jenis Kelamin } \\
\hline - Laki-laki & 96 & 28,6 \\
\hline - Perempuan & 240 & 71,4 \\
\hline \multicolumn{3}{|l|}{ Status Pernikahan } \\
\hline - Menikah & 237 & 70,5 \\
\hline - Belum Menikah & 99 & 29,5 \\
\hline \multicolumn{3}{|l|}{ Masa Kerja } \\
\hline - <5 Tahun & 95 & 28,3 \\
\hline - 5-15 Tahun & 184 & 54,8 \\
\hline - >15 Tahun & 57 & 17,0 \\
\hline \multicolumn{3}{|l|}{ Frekuensi Kontak } \\
\hline - $\leq 1$ kali & 15 & 4,5 \\
\hline - $2-5$ kali & 76 & 22,6 \\
\hline - $6-10$ kali & 34 & 10,1 \\
\hline . $>10$ kali & 211 & 62,8 \\
\hline \multirow{2}{*}{\multicolumn{3}{|c|}{$\begin{array}{l}\text { Area Kerja Selama } \\
\text { Pandemi }\end{array}$}} \\
\hline & & \\
\hline - Isolasi/ khusus & 93 & 27,7 \\
\hline - ICU & 84 & 25,0 \\
\hline - Rawat Biasa & 61 & 18,2 \\
\hline - UGD & 42 & 12,5 \\
\hline - $\mathrm{HCU} / \mathrm{IW}$ & 23 & 6,8 \\
\hline - Lainnya & 33 & 9,8 \\
\hline \multicolumn{3}{|l|}{ Area Kerja Sebelumnya } \\
\hline - Isolasi/ khusus & 10 & 3,0 \\
\hline - ICU & 88 & 26,2 \\
\hline - Rawat Biasa & 120 & 35,7 \\
\hline - UGD & 33 & 9,8 \\
\hline - $\mathrm{HCU} / \mathrm{IW}$ & 38 & 11,3 \\
\hline - Lainnya & 47 & 14,0 \\
\hline \multicolumn{3}{|l|}{ Status Tempat Tinqqal } \\
\hline - Rumah Pribadi & 155 & 46,1 \\
\hline - Kontrakan/ Kos & 63 & 18,8 \\
\hline $\begin{array}{l}\text { - Rumah Orang } \\
\text { Tua }\end{array}$ & 23 & 6,8 \\
\hline $\begin{array}{c}\text { - Fasilitas RS/ } \\
\text { Pemerintah }\end{array}$ & 89 & 26,5 \\
\hline - Lainnya & 6 & 1,8 \\
\hline \multicolumn{3}{|l|}{ Partner Tinggal } \\
\hline - Sendiri & 55 & 16,4 \\
\hline $\begin{array}{l}\text { - Istri/ Suami/ } \\
\text { Anak }\end{array}$ & 174 & 51,8 \\
\hline - Orang Tua/ & 22 & 6,6 \\
\hline - Temen & 85 & 25,3 \\
\hline
\end{tabular}

Berdasarkan hasil penelitian, mayoritas responden merasa dukungan dari rumah sakit yang baik (52,4\%), sedangkan sisanya merasa dukungan rumah sakit yang kurang baik. Prevalensi kecemasan pada perawat COVID-19 yaitu $51,2 \%$ dengan $27,7 \%$ mengalami cemas ringan, $20,8 \%$ mengalami cemas sedang, dan 2,7\% cemas berat. Sementara itu prevalensi depresi pada perawat COVID-19 sebesar 54,8\% dengan 25,3\% mengalami depresi ringan, $27 \%$ mengalami depresi sedang, dan 1,5\% mengalami depresi berat (tabel 2).

Tabel 2 Distribusi Frekuensi Dukungan Rumah Sakit dan Skala HADS (n:336)

\begin{tabular}{lcc}
\hline \multicolumn{1}{c}{ Variabel } & $\mathbf{n}$ & $\mathbf{( \% )}$ \\
\hline Dukungan Rumah Sakit & & \\
- Baik & 176 & 52,4 \\
- Kurang baik & 160 & 47,6 \\
Subskala Ansietas & & \\
- 0-7 (tidak cemas) & 164 & 48,8 \\
- 8-10 (cemas ringan) & 93 & 27,7 \\
- 11-15(cemas sedang) & 70 & 20,8 \\
- 16-21 (cemas berat) & 9 & 2,7 \\
Subskala Depresi & & \\
- 0-7 (tidak depresi) & 152 & 45,2 \\
- 8-10 (depresi ringan) & 85 & 25,3 \\
- 11-15(depresi sedang) & 94 & 27,0 \\
- 16-21 (depresi berat) & 5 & 1,5 \\
\hline & &
\end{tabular}

Berdasarkan hasil penelitian diketahui bahwa terdapat perbedaan yang signifikan berdasarkan alpha $5 \%$ pada skor HADS-A terhadap jenis kelamin $(p$-value $=0,014)$, status pernikahan ( $p$-value $=0,002)$, area kerja selama pandemi ( $p$-value $=$ 0,009 ), dukungan rumah sakit ( $p$-value $<0,000)$, dan HADS-D ( $p$-value < 0,000) (tabel 3). 
Tabel 3 Perbandingan Skor HADS-A (Kecemasan) Berdasarkan Karakteristik Responden, Dukungan Rumah Sakit, dan HADS-D (Depresi) ( $n=336)$

\begin{tabular}{|c|c|c|c|}
\hline \multicolumn{2}{|l|}{ Variabel } & \multirow{2}{*}{$\begin{array}{c}\text { HADS-A } \\
\text { Mean } \pm \text { SD } \\
6,9 \pm 3,7 \\
8,1 \pm 3,8\end{array}$} & $p$-value \\
\hline Jenis Kelamin & $\begin{array}{l}\text { Laki-Laki } \\
\text { Perempuan }\end{array}$ & & $0,014^{*} \mathbf{a}$ \\
\hline Rentang Usia & $\begin{array}{l}\text { 20-30 Tahun } \\
\text { 31-65 Tahun }\end{array}$ & $\begin{array}{l}7,3 \pm 3,7 \\
8,5 \pm 3,9\end{array}$ & $0,104 \mathbf{a}$ \\
\hline Status Pernikahan & $\begin{array}{l}\text { Menikah } \\
\text { Belum Menikah }\end{array}$ & $\begin{array}{l}8,2 \pm 3,8 \\
6,7 \pm 3,5\end{array}$ & $0,002^{*} \mathbf{a}$ \\
\hline Masa Kerja & $\begin{array}{l}<5 \text { Tahun } \\
5-15 \text { Tahun } \\
>15 \text { Tahun }\end{array}$ & $\begin{array}{l}7,1 \pm 3,6 \\
8,1 \pm 3,9 \\
7,5 \pm 3,8\end{array}$ & $0,128 \mathbf{b}$ \\
\hline Frekuensi Kontak & $\begin{array}{l}1 \text { Kali } \\
2-5 \text { kali } \\
6-10 \text { kali }\end{array}$ & $\begin{array}{l}8,5 \pm 3,6 \\
8,6 \pm 3,8 \\
7,9 \pm 4,1\end{array}$ & \\
\hline Area Kerja Selama Pandemi & $\begin{array}{l}>10 \text { kali } \\
\text { Isolasi/ Khusus } \\
\text { ICU } \\
\text { Rawat Biasa } \\
\text { UGD } \\
\text { HCU/IW }\end{array}$ & $\begin{array}{l}7,4 \pm 3,8 \\
7,2 \pm 3,9 \\
8,1 \pm 3,6 \\
8,5 \pm 3,7 \\
6,4 \pm 3,6 \\
7,1 \pm 4,2\end{array}$ & $0,119 \mathbf{b}$ \\
\hline & Lainnya & $9.1 \pm 3,7$ & $0,009 * \mathbf{b}$ \\
\hline Area Kerja Sebelumnya & $\begin{array}{l}\text { Isolasi/ Khusus } \\
\text { ICU } \\
\text { Rawat Biasa } \\
\text { UGD } \\
\text { HCU/IW } \\
\text { Lainnya }\end{array}$ & $\begin{array}{l}5,9 \pm 2,8 \\
8,1 \pm 3,8 \\
8,0 \pm 3,6 \\
6,4 \pm 4,0 \\
7,4 \pm 3,9 \\
8,0 \pm 4,2\end{array}$ & $0.148 \mathbf{b}$ \\
\hline Status Tempat Tinggal & $\begin{array}{l}\text { Rumah Pribadi } \\
\text { Kontrakan/Kos } \\
\text { Rumah Orang Tua } \\
\text { Fasilitas RS/ } \\
\text { Pemerintah } \\
\text { Lainnya }\end{array}$ & $\begin{array}{l}7,9 \pm 3,9 \\
7,4 \pm 3,3 \\
9,3 \pm 3,8 \\
7,3 \pm 4,0 \\
8,7 \pm 3,0\end{array}$ & $0,253 \mathbf{b}$ \\
\hline Partner Tinggal & $\begin{array}{l}\text { Sendiri } \\
\text { Istri/Suami/Anak } \\
\text { Orang Tua/ } \\
\text { Saudara } \\
\text { Teman }\end{array}$ & $\begin{array}{l}6,8 \pm 3,5 \\
8,2 \pm 3,7 \\
8,0 \pm 4,2 \\
7,4 \pm 4,0\end{array}$ & $0,086 \mathbf{b}$ \\
\hline Dukungan RS & & & $0,000^{*} \mathbf{c}$ \\
\hline HADS-D & & & $0,000^{*} \mathbf{c}$ \\
\hline
\end{tabular}

a. Mann-Whitney U test b. Kruskal-Wallis test $c$. Kendall's tau coefficient; ${ }^{*} p<0.05$

Hasil dari analisa bivariat value 0.02), dukungan rumah sakit ( $p$ menggunakan Spearman Rho value $<0.00)$, dan tingkat depresi $(p$ Correlation menunjukkan bahwa value $<0.00$ ). Sementara itu variabel terdapat tiga variabel yang memiliki lainnya tidak memiliki pengaruh yang hubungan/ pengaruh yang signifikan ( $p$ value $<0.05)$ dengan tingkat signifikan terhadap tingkat kecemasan $(p$-value $>0.05)$ (tabel 4).

kecemasan yaitu status pernikahan $(p$ - 
Tabel 4. Hubungan Karakteristik Responden, Dukungan Rumah Sakit, Dan Tingkat Depresi dengan Tingkat Kecemasan ( $n=336)$

\begin{tabular}{|c|c|c|c|c|c|c|}
\hline \multirow{2}{*}{ Variabel } & & \multicolumn{4}{|c|}{$\begin{array}{c}\text { Tingkat Kecemasan Berdasarkan Skor } \\
\text { HADS-A }\end{array}$} & \multirow[b]{2}{*}{$\begin{array}{c}p \text {-value } \\
\text { (koefisien) }\end{array}$} \\
\hline & & $\begin{array}{c}\text { Tidak } \\
\text { Cemas } \\
(0-7) \\
\end{array}$ & $\begin{array}{c}\text { Cemas } \\
\text { Ringan } \\
(8-10) \\
\end{array}$ & $\begin{array}{l}\text { Cemas } \\
\text { Sedang } \\
(11-15) \\
\end{array}$ & $\begin{array}{c}\text { Cemas } \\
\text { Berat } \\
(15-21) \\
\end{array}$ & \\
\hline $\begin{array}{l}\text { Jenis } \\
\text { Kelamin }\end{array}$ & $\begin{array}{l}\text { Laki-Laki } \\
\text { Perempuan, }\end{array}$ & $\begin{array}{c}55(57,3) \\
109(45,4)\end{array}$ & $\begin{array}{l}22(22,9) \\
71(29,6)\end{array}$ & $\begin{array}{l}18(18,8) \\
52(21,7)\end{array}$ & $\begin{array}{l}1(1,0) \\
8(3,3)\end{array}$ & $\begin{array}{c}0.060 \\
(0.103)\end{array}$ \\
\hline $\begin{array}{l}\text { Rentang } \\
\text { Usia }\end{array}$ & $\begin{array}{l}\text { 20-30 Tahun } \\
\text { 30-65 Tahun }\end{array}$ & $\begin{array}{l}72(53,3) \\
92(45,8)\end{array}$ & $\begin{array}{l}38(28,1) \\
55(27,4)\end{array}$ & $\begin{array}{l}22(16,3) \\
48(23,9)\end{array}$ & $\begin{array}{l}3(2,2) \\
6(3,0)\end{array}$ & $\begin{array}{c}0.092 \\
(1.000)\end{array}$ \\
\hline $\begin{array}{l}\text { Status } \\
\text { Pernikahan }\end{array}$ & $\begin{array}{l}\text { Menikah } \\
\text { Belum Menikah }\end{array}$ & $\begin{array}{c}105(44,3) \\
59(59,6)\end{array}$ & $\begin{array}{l}66(27,8) \\
27(27,3)\end{array}$ & $\begin{array}{l}58(24,5) \\
12(12,1)\end{array}$ & $\begin{array}{l}8(3,4) \\
1(1,0)\end{array}$ & $\begin{array}{l}0.002^{*} \\
(0.166)\end{array}$ \\
\hline Masa Kerja & $\begin{array}{l}<5 \text { Tahun } \\
5-15 \text { Tahun } \\
>15 \text { Tahun }\end{array}$ & $\begin{array}{l}51(53,7) \\
81(44,0) \\
32(56,1)\end{array}$ & $\begin{array}{l}29(30,5) \\
52(28,3) \\
12(21,1)\end{array}$ & $\begin{array}{l}14(14,7) \\
45(24,5) \\
11(19,3)\end{array}$ & $\begin{array}{l}1(1,1) \\
6(3,3) \\
2(3,5)\end{array}$ & $\begin{array}{l}0.450 \\
(0.041)\end{array}$ \\
\hline $\begin{array}{l}\text { Frekuensi } \\
\text { Kontak }\end{array}$ & $\begin{array}{l}1 \text { Kali } \\
2-5 \text { kali } \\
6-10 \text { kali } \\
>10 \text { kali }\end{array}$ & $\begin{array}{c}7(46,7) \\
31(40,8) \\
16(47,1) \\
110(52,1)\end{array}$ & $\begin{array}{c}2(13,3) \\
23(30,3) \\
12(35,3) \\
56(26,5)\end{array}$ & $\begin{array}{c}6(40,0) \\
18(23,7) \\
3(8,8) \\
43(20,4)\end{array}$ & $\begin{array}{l}0(0,0) \\
4(5,3) \\
3(8,8) \\
2(0,9)\end{array}$ & $\begin{array}{c}0.055 \\
(-0.105)\end{array}$ \\
\hline Area Kerja & Isolasi/ Khusus & $53(57,0)$ & $21(22,6)$ & $16(17,2)$ & $3(3,2)$ & 0.194 \\
\hline $\begin{array}{l}\text { Selama } \\
\text { Pandemi }\end{array}$ & $\begin{array}{l}\text { ICU, } \\
\text { Rawat Biasa } \\
\text { UGD } \\
\text { HCU/IW } \\
\text { Lainnya }\end{array}$ & $\begin{array}{l}38(45,2) \\
24(39,3) \\
25(59,5) \\
14(60,9) \\
10(30,3)\end{array}$ & $\begin{array}{c}26(31,0) \\
19(31,1) \\
12(28,6) \\
2(8,7) \\
13(39,4)\end{array}$ & $\begin{array}{l}18(21,4) \\
16(26,2) \\
5(11,9) \\
7(30,4) \\
8(24,2)\end{array}$ & $\begin{array}{l}2(2,4) \\
2(3,3) \\
0(0,0) \\
0(0,0) \\
2(6,1)\end{array}$ & $(0.071)$ \\
\hline $\begin{array}{l}\text { Area Kerja } \\
\text { Sebelumnya }\end{array}$ & $\begin{array}{l}\text { Isolasi/ Khusus } \\
\text { ICU } \\
\text { Rawat Biasa } \\
\text { UGD } \\
\text { HCU/IW } \\
\text { Lainnya }\end{array}$ & $\begin{array}{c}7(70,0) \\
42(47,7) \\
54(45,0) \\
21(63,6) \\
19(50,0) \\
21(44,7)\end{array}$ & $\begin{array}{c}3(30,0) \\
24(27,3) \\
36(30,0) \\
6(18,2) \\
12(25,5) \\
12(25,5)\end{array}$ & $\begin{array}{c}0(0,0) \\
19(21,6) \\
28(23,3) \\
6(18,2) \\
5(13,2) \\
12(25,5)\end{array}$ & $\begin{array}{l}0(0,00 \\
3(3,4) \\
2(1,7) \\
0(0,0) \\
2(5,3) \\
2(4,3)\end{array}$ & $\begin{array}{c}0.772 \\
(0.016)\end{array}$ \\
\hline Status & Rumah Pribadi & $76(49,0)$ & $41(26,5)$ & $33(21.3)$ & $5(3,2)$ & 0.925 \\
\hline $\begin{array}{l}\text { Tempat } \\
\text { Tinggal }\end{array}$ & $\begin{array}{l}\text { Kontrakan/Kos } \\
\text { Rumah Orang Tua } \\
\text { RS } \\
\text { Lainnya }\end{array}$ & $\begin{array}{c}31(49,2) \\
8(34,8) \\
46(51,7) \\
3(50,0)\end{array}$ & $\begin{array}{c}21(33,3) \\
7(30,4) \\
24(27,0) \\
0(0,0)\end{array}$ & $\begin{array}{c}11(17,5) \\
7(30,4) \\
16(18,0) \\
3(50,0)\end{array}$ & $\begin{array}{l}0(0,0) \\
1(4,3) \\
3(3,4) \\
0(0,0)\end{array}$ & $(-0.005)$ \\
\hline $\begin{array}{l}\text { Partner } \\
\text { Tinggal }\end{array}$ & $\begin{array}{l}\text { Sendiri } \\
\text { Istri/Suami/Anak } \\
\text { Orang Tua/Saudara } \\
\text { Teman }\end{array}$ & $\begin{array}{l}30(54,5) \\
77(44,3) \\
12(54,5) \\
45(52,9)\end{array}$ & $\begin{array}{c}17(30,9) \\
51(29,3) \\
5(22,7) \\
20(23,5)\end{array}$ & $\begin{array}{c}8(14,5) \\
41(23,6) \\
4(18,2) \\
17(20,0)\end{array}$ & $\begin{array}{l}0(0,00 \\
5(2,9) \\
1(4,5) \\
3(3,5)\end{array}$ & $\begin{array}{c}0.894 \\
(0.007)\end{array}$ \\
\hline $\begin{array}{l}\text { Dukungan } \\
\text { RS }\end{array}$ & $\begin{array}{l}\text { Kurang } \\
\text { Baik }\end{array}$ & $\begin{array}{c}59(36,9) \\
105(59,7)\end{array}$ & $\begin{array}{l}44(27,5) \\
49(27,8)\end{array}$ & $\begin{array}{l}49(30,6) \\
21(11,9)\end{array}$ & $\begin{array}{l}8(5,0) \\
1(0,6)\end{array}$ & $\begin{array}{c}0.000^{*} \\
(-0.278)\end{array}$ \\
\hline $\begin{array}{l}\text { Tingkat } \\
\text { Depresi }\end{array}$ & $\begin{array}{l}\text { Tidak depresi } \\
\text { Depresi ringan } \\
\text { Depresi Sedang } \\
\text { Depresi Berat } \\
\end{array}$ & $\begin{array}{c}108(71,1) \\
34(40,0) \\
21(22,3) \\
1(20,0) \\
\end{array}$ & $\begin{array}{c}34(22,4) \\
21(24,7) \\
38(40,4) \\
0(0,0)\end{array}$ & $\begin{array}{c}8(5,3) \\
30(35,3) \\
29(30,9) \\
3(60,0)\end{array}$ & $\begin{array}{l}2(1,3) \\
0(0,0) \\
6(6,4) \\
1(20,0)\end{array}$ & $\begin{array}{l}0.000^{*} \\
(0.451)\end{array}$ \\
\hline
\end{tabular}

${ }^{*} p<0.05$ atau signifikan pada alpha $5 \%$, Uji Spearman Rho Correlation

Pembahasan

Ansietas (kecemasan) merupakan rasa takut yang tidak jelas disertai dengan perasaan ketidakpastian, ketidakberdayaan, isolasi, serta ketidakamanan. Seseorang dengan 
gangguan kecemasan mengalami kerusakan pada kualitas dan fungsi hidup. Namun demikian, kecemasan merupakan bagian dari kehidupan sehari-hari yang diperlukan untuk bertahan hidup. kecemasan juga dikomunikasikan secara interpersonal, artinya, memiliki sifat menular yang dapat memiliki efek positif maupun negatif dalam hubungan terapeutik. ${ }^{(5)}$ Kecemasan yang terjadi pada seorang perawat COVID-19 dapat menular pada teman sejawatnya sesama perawat atau bahkan lebih jauh kepada pasien. Bila respon kecemasan yang terjadi pada seorang tenaga kesehatan menjadi maladaptif dan semakin meluas, maka hal tersebut dapat menggangu proses penanganan dan pengendalian dari pandemi COVID-19 itu sendiri.

Gangguan kecemasan cenderung lebih banyak terjadi pada wanita. Perubahan hormonal selama haid, hamil, menyusui, serta menopause dapat mempengaruhi mood serta menyebabkan depresi yang dapat meningkatkan kecemasan. $\mathrm{Hal}$ ini senada dengan penelitian dari Tang et al., , Özdin \& Özdin, Lai et al., dan Pappa et al. ${ }^{(2)(3)(6)(7)}$ Dalam penelitian ini terdapat perbedaan skor HADS-A yang signifikan pada laki-laki dan perempuan, secara berurutan $6,9 \pm 3,7$ dan 8,1 \pm 3,8 (mean \pm SD) yang menunjukkan bahwa perempuan cenderung memiliki skor HADS-A (skala kecemasan) yang lebih tinggi dibandingkan laki-laki; dengan $p$-value 0.014. Namun demikian, tidak terdapat pengaruh yang signifikan pada jenis kelamin terhadap tingkat kecemasan ( $p$-value $0.060 ; r=0,103$ ). Sama halnya dengan penelitian dari Diaz dan Aziza serta Lu, Wang, Lin, dan Li yang menunjukkan tidak ada perbedaan atau pengaruh yang signifikan antara jenis kelamin dengan tingkat kecemasan. ${ }^{(8)(9)}$ Untuk itu perlu penelitian lebih lanjut menggunakan metodologi dan teknik sampling yang lebih baik untuk mengetahui hubungan antara gender/ jenis kelamin dengan tingkat kecemasan.

Usia responden dari penelitian ini ada pada rentang usia 22 - 56 tahun, dengan usia responden terbanyak pada rentang 31 - 65 tahun (59,8\%). Hasil dari penelitian menemukan bahwa usia tidak memiliki pengaruh yang signifikan terhadap tingkat kecemasan ( $p$-value 0.092; $r=1.000)$. Hal ini senada dengan penelitian dari Diaz dan Aziza (2018) yang juga menemukan bahwa usia tidak mempengaruhi tingkat kecemasan. ${ }^{(8)} \mathrm{Hal}$ ini berbeda dengan studi yang menyebutkan bahwa usia adalah prediktor signifikan pada 
kecemasan dimana seiring

bertambahnya usia, kecemasan

cenderung berkurang. ${ }^{(10)}$ Usia juga

diketahui merupakan prediktor

terjadinya Post Traumatic Stress

Dissorder (PTSD) pada pekerja medis selama wabah avian influenza.(3)

Perbedaan ini dimungkinkan karena adanya perbedaan dari metodologi, karakteristik responden, rentang usia, dan atau cut off usia dari masingmasing penelitian.

Status pernikahan/ keluarga memiliki pengaruh yang signifikan terhadap tingkat kecemasan perawat COVID-19 ( $p$-value 0.002; $r=0.166$ ). Perawat yang telah menikah/ berkeluarga cenderung memiliki angka kecemasan yang lebih tinggi dibandingkan dengan perawat yang belum menikah. Hal ini didukung oleh penelitian dari Ta, Gesselman, Perry, Fisher, \& Garcia yang menemukan bahwa status perkawinan dapat memiliki implikasi penting bagi perilaku sosial, kesehatan, dan kesejahteraan, dan efeknya pada stress. ${ }^{(11)}$ Berbeda halnya dengan penelitian dari Nieder \& Kämpe (2018) serta Diaz \& Aziza yang menemukan bahwa tidak ada hubungan yang signifikan antara status pernikahan dengan tingkat kecemasan. ${ }^{(8)(12)} \mathrm{Hal}$ ini didukung juga oleh studi Özdin \& Özdin pada populasi masyarakat umum di
Turki.yang menemukan tidak adanya perbedaan tingkat kecemasan yang signifikan pada individu yang belum menikah dengan yang telah menikah selama pandemi COVID-19. ${ }^{(7)}$

Tidak ada pengaruh yang signifikan antara frekuensi kontak dengan tingkat kecemasan. Berdasarkan data penelitian, prevalensi kecemasan cenderung meningkat pada kontak pertama kali hingga kontak ke lima dengan pasien COVID-19, kemudian terus menurun setelah kontak ke 6 dan semakin rendah setelah kontak lebih dari 10 kali. Namun demikian, hal ini tidak terlalu bermakna ( $p$-value $0.055 ; r=-0.105$ ). Hal ini bertolak belakang dengan hipotesis peneliti dan berdasarkan penelitian sebelumnya dari Tang et al. bahwa frekuensi kontak yang tinggi dengan pasien COVID-19 akan meningkatkan stress dan pada akhirnya akan meningkatkan kecemasan pada perawat.(3) Untuk itu perlu dilakukan penelitian lanjutan untuk mengetahui hal tersebut.

Mayoritas responden pada penelitian ini selama pandemi atau saat ini bekerja di ruang isolasi/khusus perawatan COVID-19 (27,7\%). Sedangkan sebelum pandemi, mayoritas responden bekerja di ruang perawatan biasa $(35,7 \%)$. Dari data penelitian juga diperoleh mobilisasi 
perawat dari ruangan-ruangan lainnya sebagai tambahan tenaga perawat di ruang Isolasi/ khusus COVID-19 selama pandemi. Berdasarkan hasil penelitian, area kerja selama pandemi tidak memiliki pengaruh yang signifikan terhadap tingkat kecemasan pada perawat COVID-19 ( $p$-value 0.194; $r=$ 0.071). Begitu juga area kerja sebelum pandemi tidak memiliki pengaruh yang signifikan terhadap tingkat kecemasan pada perawat COVID-19 ( $p$-value $0.772 ; r=0.016)$. Hal ini senada dengan studi dari Tang et al. yang juga menemukan bahwa area kerja tidak signifikan mempengaruhi tingkat post traumatic distress syndrome (PTSD) pada perawat selama pandemi.(3) $\mathrm{Hal}$ ini berbeda dengan studi dari Li et al. yang menunjukkan bahwa perawat non-garis depan lebih cenderung menderita masalah psikologis dibandingkan perawat garis depan, dikarenakan daya tahan psikologis perawat garis depan yang cenderung lebih kuat. ${ }^{(2)}$

Hasil penelitian ini menunjukkan bahwa status tempat tinggal dan partner tinggal tidak memiliki pengaruh yang signifikan terhadap tingkat kecemasan. Namun demikian berdasarkan data penelitian, skor HADS-A pada perawat yang tinggal sendiri $(6,8 \pm 3,5)$ atau bersama teman
$(7,4 \pm 4,0)$ relatif lebih rendah dibandingkan skor HADS-A pada perawat yang tinggal bersama orangtua/ saudaranya $(8,0 \pm 4,2)$ serta bila dibandingkan dengan perawat yang tinggal bersama istri/suami/anaknya $(8,2 \pm 3,7)$ dengan $p$-value 0.086 (tidak signifikan) (tabel 3). Hal ini dapat terjadi karena kekhawatiran untuk menularkan penyakit COVID-19 lebih tinggi bila tinggal bersama keluarganya dibandingkan bila tinggal sendiri atau dengan teman sejawatnya. Namun, butuh penelitian lebih lanjut untuk menganalisa hal tersebut. Untuk saat ini belum diperoleh data studi yang relevan/ terkait dari pengaruh tempat tinggal dan partner tinggal terhadap tingkat kecemasan pada perawat.

Penelitian ini menunjukkan bahwa dukungan dari rumah sakit berpengaruh signifikan terhadap tingkat kecemasan perawat COVID-19 selama pandemi ( $r=-0,278)$. Artinya bahwa semakin baik dukungan rumah sakit maka tingkat kecemasan pada perawat akan berkurang. Hal tersebut diatas sejalan dengan studi literatur yang menemukan bukti bahwa pelatihan kognitif-perilaku dapat mengurangi stres sampai dengan $13 \%$ pada petugas kesehatan bila dibandingkan dengan tidak adanya pelatihan. Selain itu, terdapat juga bukti yang 
menunjukkan bahwa relaksasi mental dan fisik dapat mengurangi stres pada petugas Kesehatan hingga 23\%. Lebih lanjut, terdapat bukti yang menunjukkan bahwa intervensi dari organisasi/ institusi dengan mengurangi jam kerja atau menambah jeda waktu libur dapat menurunkan tingkat stres pada petugas kesehatan. ${ }^{(13)}$

Sejumlah penelitian lainnya juga menunjukkan dukungan sosial sangat penting untuk menjaga kesehatan fisik dan psikologis. Konsekuensi yang berbahaya dari dukungan sosial yang buruk dan efek perlindungan dari dukungan sosial yang baik terhadap penyakit mental telah didokumentasikan dengan baik. Dukungan sosial dapat memoderasi kerentanan genetik dan lingkungan dan memberikan ketahanan terhadap stres, yang dapat terjadi melalui pengaruhnya terhadap sistem hipotalamuspituitariadrenokortikal (HPA), sistem noradrenergik, dan jalur oksitosin sentral. ${ }^{(14)}$

Pada penelitian ini, tingkat depresi memiliki pengaruh yang signifikan terhadap tingkat kecemasan $(r=451)$. Hal ini sejalan dengan studi literatur dari 9 penelitian sebelumnya oleh Stavrakaki \& Vargo yang menunjukkan bahwa depresi berkorelasi dengan kecemasan. ${ }^{15)}$ Hal ini juga didukung oleh penelitian terbaru dari Diaz \&
Aziza serta Kalin yang juga menunjukkan bahwa depresi berkorelasi dengan kecemasan. ${ }^{(8)(16)}$

Hubungan antara depresi dan kecemasan dapat dijelaskan dengan Tripartite model of anxiety and depression oleh Clark and Watson dalam Diaz \& Aziza melalui penjabaran dari munculnya tiga gejala utama yaitu afek negatif, afek positif, dan kondisi psikologis hiperarousal. Rendahnya afek positif merupakan faktor kemunculan depresi. Sementara itu, kondisi psikologis hiperarousal berhubungan erat dengan gejala ansietas. Pada akhirnya, afek negatif yang didominasi kondisi perasaan yang buruk seperti mudah lelah, merasa tertekan, insomnia, merasa sendiri merupakan faktor untuk ansietas dan depresi. $^{(8)} \quad$ Sementara itu, Kalin melaporkan bahwa $45,7 \%$ orang dengan gangguan depresi berat seumur hidup memiliki riwayat satu atau lebih gangguan kecemasan. Selain itu $41,6 \%$ orang dengan depresi berat dalam 12 bulan terakhir juga memiliki satu atau lebih gangguan kecemasan selama periode yang sama. Selain itu ditemukan bahwa gangguan kecemasan umumnya mendahului presentasi gangguan depresi mayor. ${ }^{(16)}$

Penelitian ini memiliki beberapa keterbatasan. Pertama, kuesioner dikirimkan secara non-acak melalui 
whatsapp dan atau facebook messenger, sehingga dapat membuat bias selektif dalam penelitian kami. Penelitian menggunakan kuesioner juga memiliki kelemahan dimana peneliti tidak dapat melihat reaksi responden ketika memberikan informasi melalui isian kuesioner. Terdapat pula resiko jawaban yang diberikan responden tidak sesuai dengan kondisi sebenarnya/ asalasalan. Kedua, sebagian besar responden berasal dari rumah sakit di DKI Jakarta (47,3\%) yang berarti bahwa penelitian ini tidak menggambarkan sepenuhnya seluruh perawat yang ada di Indonesia. Hal tersebut juga terkait dengan sulitnya memperoleh responden dari luar DKI Jakarta karena keterbatasan waktu dan hambatan-hambatan dalam pengurusan perizinan/ rekomendasi penelitian selama pandemi COVID-19. Ketiga, pengumpulan data tidak dilakukan selama tahap awal pandemi, dimana tingkat skor kecemasan bisa saja berbeda. Sebuah studi sebelumnya melaporkan bahwa prevalensi gangguan psikologis disajikan secara berbeda dari awal hingga akhir wabah. Keempat, penelitian ini menggunakan desain cross-sectional yang tidak dapat menentukan kausalitas untuk faktor dan hasil.

\section{Kesimpulan}

Status pernikahan, dukungan rumah sakit dan tingkat depresi merupakan faktor-faktor yang berkaitan dengan tingkat kecemasan pada perawat COVID-19 di rumah sakit.

\section{Saran}

Strategi dukungan psikososial untuk mengurangi tingkat kecemasan pada perawat melalui pelatihan kognitifperilaku dan relaksasi, selain itu perlunya dukungan rumah sakit yang baik, dalam hal ini berupa penyediaan APD yang memadai, tersedianya standar prosedur operasional (SPO) yang jelas, dilakukannya pelatihan pelatihan yang terkait dengan COVID19.

\section{Ucapan Terima Kasih}

Penulis mengucapkan terimakasih para perawat pejuang COVID-19 dan kepada semua pihak yang berkonstribusi dalam penelitian ini.

\section{Daftar Pustaka}

1. Zhu $H$, Wei L, Niu P. The novel coronavirus outbreak in Wuhan, China. Glob Heal Res policy [Internet]. $2020 \quad$ Mar 2;5:6. 
Available from: https://pubmed. ncbi.nlm.nih.gov/32226823

2. Lai J, Ma S, Wang Y, Cai Z, Hu J, Wei $\mathrm{N}$, et al. Factors Associated With Mental Health Outcomes Among Health Care Workers Exposed to Coronavirus Disease 2019. JAMA Netw open [Internet]. 2020 Mar 2;3(3):e203976e203976. Available from: https://pubmed.ncbi.nlm.nih.gov/32 202646

3. Tang L, Pan L, Yuan L, Zha L, Zhu $H$, Wei L, et al. Prevalence and related factors of post-traumatic stress disorder among medical staff members exposed to H7N9 patients. Int J Nurs Sci [Internet]. 2017 Dec 11;4(1):6. Available from: https://pubmed.ncbi.nlm.nih.gov/32 226823

4. Rudy M, Widyadharma E, Adnyana O. Reliability Indonesian Version Of The Hospital Anxiety And Depression Scale (HADS) Of Stroke Patients In Sanglah General Hospital Denpasar. 2015.

5. Stuart GW. Principles and Practice of Psychiatric Nursing. 10th ed. Vol. 81, The American Journal of Nursing. Missouri: Mosby, Inc; 2013. 2226 p.

6. Pappa S, Ntella V, Giannakas T, Giannakoulis VG, Papoutsi E, Katsaounou P. Prevalence of depression, anxiety, and insomnia among healthcare workers during the COVID-19 pandemic: A systematic review and metaanalysis. Brain Behav Immun [Internet]. 2020;(May):1-7. Available from: https://doi.org/ 10.1016/j.bbi.2020.05.026

7. Özdin S, Bayrak Özdin Ş. Levels and predictors of anxiety, depression and health anxiety during COVID-19 pandemic in Turkish society: The importance of gender. Int J Soc Psychiatry. 2020;

8. Diaz Y, Aziza A. SURVEI TINGKAT ANSIETAS ORANG TUA YANG MERAWAT ANAK PENGIDAP KANKER DI INDONESIA [Internet]. Vol. 18, Indonesian Journal of Nursing Sciences and Practice. 2018 [cited 2020 Jun 25]. Available from: https://jurnal.umj.ac.id/index.php/ijn sp/article/view/2698

9. Lu W, Wang $H$, Lin $Y, L i ~ L$. Psychological status of medical workforce during the COVID-19 pandemic: A cross-sectional study. Psychiatry Res [Internet]. 2020/04/04. 2020 Jun;288:112936. Available from: https://pubmed. ncbi.nlm.nih.gov/32276196

10. Weiss Wiesel TR, Nelson CJ, Tew WP, Hardt M, Mohile SG, Owusu $\mathrm{C}$, et al. The relationship between 
age, anxiety, and depression in

older adults with cancer.

Psychooncology [Internet].

2014/08/06. 2015 Jun;24(6):712-7.

Available from: https://pubmed .ncbi.nlm.nih.gov/25099337

11. Ta VP, Gesselman AN, Perry BL, Fisher HE, Garcia JR. Stress of Singlehood: Marital Status, Domain-Specific Stress, and Anxiety in a National U.S. Sample. J Soc Clin Psychol [Internet]. 2017 Jun 1;36(6):461-85. Available from: https://doi.org/10.1521/ jscp.2017.36.6.461

12. Nieder C, Kämpe TA. Does Marital Status Influence Levels of Anxiety and Depression Before Palliative Radiotherapy? In Vivo [Internet]. 2018;32(2):327-30. Available from: https://pubmed.ncbi.nlm.nih.gov/29 475916

13. Ruotsalainen $\mathrm{JH}$, Verbeek $\mathrm{JH}$, Mariné A, Serra C. Preventing occupational stress in healthcare workers. Cochrane database Syst Rev [Internet]. 2015 Apr 7;2015(4):CD002892-CD002892.

Available from: https://pubmed. ncbi.nlm.nih.gov/25847433

14. Ozbay F, Johnson DC, Dimoulas E, Morgan CA, Charney D, Southwick S. Social support and resilience to stress: from neurobiology to clinical practice. Psychiatry (Edgmont) [Internet]. 2007 May;4(5):35-40. Available from: https://pubmed.ncbi.nlm.nih .gov/20806028

15. Stavrakaki C, Vargo B. The Relationship of Anxiety and Depression: A Review of the Literature. $\mathrm{Br} \quad \mathrm{J}$ Psychiatry [Internet]. 2018/01/29. 1986;149(1):7-16. Available from: https://www.cambridge.org/core/arti cle/relationship-of-anxiety-anddepression-a-review-of-theliterature/129CD24B29008EF2A51 1C3372BA364E0

16. Kalin NH. The Critical Relationship Between Anxiety and Depression. Am J Psychiatry [Internet]. 2020 May 1;177(5):365-7. Available from: https://doi.org/10.1176/appi. ajp.2020.20030305. 